\title{
The Impact of Genre-Based Instruction on Iranian Intermediate EFL Learners' Writing Skills
}

\author{
Atefeh Mohseni* \\ Civil Aviation Technology College of Tehran, Tehran - Iran
}

\begin{abstract}
The teaching of writing skills includes different methods and approaches. English language learners should be equipped with genre-based pedagogy to be able to write for specific settings. However, the idea of using Genrebased instruction of writing in non-native English-speaking countries has empirically received inadequate attention. This study aimed to investigate the impact of GBI on writing skills. Genres are Argumentative, Discussion, Explanation, and Exposition. This study used a quasi-experimental design. Fifty-one male students majoring in aviation courses in civil aviation technology of Tehran with an intermediate level of proficiency were assigned to experimental and control groups. The author examined their proficiency by Michigan English language assessment Battery (MELAB test) and tested their writing skills by administering a writing test of TOEFL iBT 2008. The control group took part in the traditional teaching of writing, and the experimental group was taught explicitly through the GBI method based on a lesson plan proposal. Four pre-and post-tests were taken by two groups to check the writing GBI progress. Independent sample t-tests revealed that the writing GBI could significantly improve the coherence, cohesion, and organization of writing. This study can benefit EFL practitioners by shedding light on how we can implement $\mathrm{GBI}$ of writing in an authentic classroom situation.
\end{abstract}

Article Information

Received 24 January 2022

Accepted 06 February 2022

Published February 11, 2022

Keywords: coherence; cohesion; genre-based instruction; organization; writing skills

\section{Introduction}

While Teaching writing is instructed in EFL and ESL contexts, it is still one of the most challenging skills in EFL settings as learners are rarely exposed to the English language spoken environments. According to Zare-ee ( 2009), teaching writing skills has been neglected in the past years due to some movement in English language teaching, and ELT practitioners mostly emphasized oral communication skills training.

\footnotetext{
*Corresponding Author: Atefeh Mohseni (atefeh_mohseni89@yahoo.com) Tehran Province, Tehran, District 9, Meraj Blvd, Iran ,Civil Aviation Technology College
}

In the history of language teaching methodology, many approaches paid attention to developing communication skills, such as CLT, audio-lingual, and other methods. However, EFL learners have many problems in writing skills. First, they should consider many structural issues such as selecting proper words, using correct grammar, and generating and developing ideas about specific topics. More significantly, they should remember it that developing functional aspects in writing is a very important dimension.

English language teachers have employed different approaches and theories. Badger and White (2000) confirmed "Product and Process 
approaches" as dominant ones (p.153). The Product approach aims to write a composition by imitating and manipulating different patterns. It was the most dominant approach of writing from the 1940s to the 1960s, and it was assumed that the writer should have a good command of grammar and lexical knowledge. These approaches deal with the end product and textual form. They place less emphasis on the writers' cognitive processes and ascribe intrinsic value to the formal characteristics of texts. They do not focus on how a particular audience should be addressed or a specific communicative purpose should be fulfilled.

According to Negari (2011), teaching writing from mid-1970 has changed from product approach to process approach. In responding to the product approach that insisted on the end product of composition, the process approach emphasizes students' cognitive process of writing on different topics they are interested in or prefer more. Teaching writing aims to help students compose a text to express events and thoughts coherently and persuasively. Since grammar instruction did not improve students' writing in previous approaches, researchers investigated the process of writing. The classroom is not for dictating forms and structures; instead, the teacher focuses on teaching different writing processes, including brainstorming, drafting, writing, revising, and editing. Teachers guide these activities in a nonlinear and recursive manner, and new writing ideas are discovered, generated, and explored. Due to the lack of students' exposure to the real language in the EFL context, students are not prepared to write for specific settings, as it happens in ESP (in English for academic purposes). Writing for specific social needs is closely related to writing different things such as business letters, academic reports, or research papers.

Tangpermpoon (2008) believes that writing in a genre-based approach combines a particular genre knowledge and its communicative goals, leading to learners' successful communication with others in the same discourse community. However, the dominant focus is on audience needs and writing teaching and learning in a new discourse community while genres are mostly used. The teacher exposes learners to different target texts and draws their attention to the structure of different compositions. As a result, they will become aware of reader expectations of a text and fulfill those needs in textual features and appropriate linguistic ties. This kind of instruction provides students with a framework to compose their written text. As a result, their self-confidence and attitude towards language learning will be enhanced. Furthermore, the genre-based approach enhances self-confidence in students' performances and equips them to write for different settings and purposes.

In EFL contexts, exposure to the English language is restricted only to a few hours per week. Therefore, teaching writing skills in the EFL context mostly emphasizes the product and process approach in which the former emphasizes the written text and the latter emphasizes the writing process. When written text produced by L2 learners is weak, one primary source of weakness is usually the lack of conformity with the norms of the target speech community (Zare-ee, 2009). Through traditional writings such as product and process approaches, teachers rely on grammatical 
structures and fixed sequences of writing stages and make them write without considering its specific context. On the other hand, a teacher implementing genre-based approaches gets learners to produce texts based on the audience, purpose, and organization. Proponents of genre-based approaches argue that its pedagogies help students learn what they need to study in every context.

In recent years, English language teaching and learning have focused on the notion of genre and genre pedagogies (Hyland, 2007). Hyland adds that genre-based pedagogies provide explicit instruction to understand the outcome of writing tasks. Genre-based pedagogy helps learners understand every text discourse and context of every kind of written text (Hyland, 2003). Genre knowledge includes knowledge of the communicative purpose of the genre, knowledge of the appropriate forms (i.e., schematic structure and lexicogrammatical features) needed to construct and interpret texts, knowledge of content and register, and knowledge of the context in which genre is found (Hyland, 2003).

Through GBI of writing, students are empowered to participate in different writing activities as soon as they acquire the skills needed. Genre-based instruction of writing has also been very effective in developing writing skills in the native language. According to Kay and Dudley-Evans (1986), GBI effectively increases writing proficiency for native speakers in $\mathrm{L} 2$ writing. In this approach, the concern is not so much the language itself but how groups of users use language.

This approach is mainly distinguished because of its emphasis on the language's social properties. Many language development theorists argued the social nature of writing in this approach. According to Vygotsky (1978), language and thinking are developed from the individual to social and from the social to the individual. Similarly, students should start to learn how things work out in society first and develop their ability on individual approaches and strategies later. Learners are taught the principal parts or moves of a genre and the most common linguistic features related to every move. Some genres consist of fundamental elements of functional components called move (Swales, 1990). The explicit teaching-learning cycle includes a series of stages such as modeling the target genres, then joint construction, and finally constructing the intended genre independently. Students should become aware of the importance of that target genre, the link between genres, and social contexts. They should understand how specific rhetorical patterns reflect communicative and social needs within a particular discourse community.

According to Hyon (1996), there are two main traditions in genre theory: Australian and Swalesian genre theory. The Australian is based on systemic functional theory (SFL) developed by Halliday ( 1985) and is known as Sydney school in the United States. Sydney school refers to the genre as text types. It attempts to provide a linguistic framework to categorize genres in different text types, e.g., narrative, argumentative, exposition, and discussion (Hyland, 2007). This school is mainly rooted in the Halladiyan concept of text type, and as Hyland (2007) asserts, both Halliday and Vygotsky have a complementary concept about language concepts. According to Hyland (ibid), the Scaffolding theory of Vygotsky (1978) has 
influenced TLC (teaching-learning cycle) as an instructional tool in which phases like modeling and joint negotiation provide instruction to students. The scaffolding theory believes that effective and efficient learning occurs when learners interact with someone more knowledgeable. As a result, students receive assistance within the Zone of proximal development (ZPD), and they can gradually write effectively with or without the teacher's assistance (Vygotsky, 1978).

Sydney School believes that if students want to be successful in writing, they should get assistance from their tutors or tutees. This assistance is called scaffolding, in which the students write a text independently through modeling, discussing all the text features, and instructing explicitly. On the other hand, in Swalesian tradition, there is a tendency to focus pedagogically on the tertiary level of language proficiency enabling students to produce the genres, especially in EAP and ESP settings (Kay \& Dudley-Evans, 1998). English for Specific purposes is another school of genre pedagogy based on the work of Swale (1990) on genre analysis, focusing on identifying critical features of genres employed in an academic setting, research articles, or professional reports.

In the ESP school of genre theory, the teacher analyzes the type of texts students need to read and produce. So, the primary concern of ESP teachers is identifying a professional group's communicative needs and preparing them for better communication. The teacher asks students to compare and manipulate samples of the target genre to extract grammar features, synthesizing building blocks in a process called rhetoric conscious raising like scaffolding (Hyland, 2007). So, it is possible to develop writing skills by assisting and guiding students to explore every essential feature of the text to construct their own written text. The past decade has witnessed a realm of research studies on writing research. Since the mid-1980s, there has been considerable attention to $\mathrm{GBI}$ of writing, and different studies have been conducted on GBI of writing impacts (Salehpour et al., 2016).

Bakhtiarvand et al. (2018) examined the impact of GBI on the writing ability of science students, employing Swales's (1990) model consisting of 3 move patterns for article introduction writing. The study showed that explicit GBI had boosted their article writing organization. The experimental study conducted by Alavi et al.(2019) showed that implicit and explicit GBI improved the writing of medical university students. Salehpour et al. (2016) performed a quasi-experimental investigation on GBl's impact in improving academic writing of twenty MA candidates majoring in ELT. This study also showed that $\mathrm{GBI}$ enhanced article writing through scaffolding and sentence starter frames.

The finding of a quasi-experimental study by Amjadiparvar et al. (2018) highlighted the efficacy of $\mathrm{GBI}$ of writing comparing the traditional product-based approach and Swales's genre-based approach. One-way ANOVA revealed that the swales group outperformed the control group (Productbased), and the GBI group outperformed the other two groups. On the other hand, the study carried out by Karimpour et al. (2016) revealed that in this quasi-experimental study, GBI of writing improved the students' rhetorical organization on text structure compared to the process approach in the control group. 
Moreover, the study by Rezvani et al. (2019), which investigated the efficacy of the genrebased approach on Iranian EFL learners' motivation for writing, revealed the significant effects and usefulness of this kind of instruction for applied linguistic syllabus designers and ELT practitioners.

In another case study, Almacioğlu and Okan (2018) highlighted the process of building metacognitive genre awareness and influencing ELLs in the English language and literature department to compose and interpret academic text professionally. The study results showed that the participants' writing ability improved and that they acquired a metacognitive awareness, at least in the declarative type of writing. Nasihin et al. (2021) concluded that GBI could improve writing research articles in social sciences and humanities. In an attempt to identify the role of GBI in writing, Haerazi et al. (2020) discovered that $\mathrm{GBI}$ is more effective than a process-based approach in teaching writing; moreover, they showed that there is a significant interaction between the GBI model and the creativity level of students.

Addressing the benefits of $\mathrm{GBI}$ in writing, Sumekto ( 2017) proposed that collaborative genre-based writing feedback from pre-service English teachers supports the students' interaction, accountability, and independence. The results showed that conducting a series of GBI of writing improved the collaborative learning of writing through positive feedback. In library research, Morgana (2017) deployed linguistic principle, pedagogical, and practical aspects of GBI of writing in a brief practical view in the Indonesian context. Finally, Phichiensathien (2018) points out the efficiency of $\mathrm{GBI}$ of writing in teaching academic writing and concludes that writing awareness in the learners` target genre increases.

The findings of a study conducted by Morell and Cesteros (2019) confirmed that GBI of writing positively affects genre knowledge and genre awareness of bilingual applied linguistic students. In a qualitative study, Allen and Goodspeed (2018) employed GBI pedagogy and approved that GBI pedagogy facilitated the literacy development of 19 advanced collegiate learners of French writing courses. The findings confirmed that genre knowledge had positive effects $O$ the accomplishment of research writing. The study showed that $\mathrm{GBI}$ could improve learners' writing literacy and provide foreign language programs with pedagogical frames related to language teaching across the curriculum. Kuiper et al. (2017) pointed to the significant growth in typical genre features, leading to the tertiary students' writing improvement through a teaching-learning cycle approach which indicated GBI potentials for promoting students' writing through interactional scaffolding strategies. Correa and Echeverri (2017) reported the gains and challenges in applying situated functional language $\mathrm{GBI}$ of writing in a written communication course qualitatively through an approach called the teaching-learning cycle. They found that one of the major GBI gains is understanding audience, settings, and purpose in a written communication course.

Another study highlighted the process of $\mathrm{GBI}$ in facilitating writing explicitly and using samples in writing as a situated social practice (Antonio et al., 2013). In another research, Troyan (2016) taught Spanish as a foreign language to fourth graders based on the 
descriptive genre and provided evidence for more detailed, informative, and cohesive writing. The study indicated the GBI potential in developing students' ability in writing appropriate to the linguistic representation of settings. Arroyo González et al. (2021) conducted quasi-experimental research to determine the effects of genre pedagogy in different dimensions such as writing metacognition, self-efficacy, and rhetorical moves of an argumentative essay. The findings demonstrated the positive effect of GBI of writing in web-based writing instruction in argumentative genre type, writing planning, and self-efficacy per se. Another quasiexperimental study by Zhang and Zhang (2021) showed that EFL learners enjoyed GBI of writing for argumentation genre, and writing improvement was realized in content and writing process; moreover, intended purpose in that specific genre and audience awareness was also enhanced.

In the same vein, Guerra-Lyons and Nayibe Rosado (2020) conducted a collaborative action research project of $\mathrm{GBI}$ of writing through explicit instruction of argumentative genre in making academic students aware of ideologies of this pedagogy. The students` argumentation writing revealed prominent command of the target genre, recommending $\mathrm{GBI}$ adaptation in academic literacy education. Another study explored genre awareness of argumentative essays in a 15-week teaching-learning cycle and concluded that the target genre's generic structure and lexico-grammar features were improved (Nagao, 2018). Some other researchers evaluated different individual responses and behavioral reactions due to the GBI of writing. Wang (2017) explored how students respond to EAP genre-based pedagogy regarding their self-direction to writing and focused merely on the assignment genre awareness. The study explored learners' characteristics that can influence learning phases in the EAP writing courses, and the students could adapt genre knowledge for other assigned writings.

Moreover, other researchers explored the English language learners' motivational changes within a genre-based pedagogy in an L2 writing instructional setting (Han \& Hiver, 2018). They indicated that $G B I$ of $L 2$ writing might lead to high levels of writing anxiety combined with a strong level of writing selfefficacy and self-regulation so that these motivational changes can offset anxiety.

Although numerous bodies of literature on GBI in different settings exist, little research has been conducted considering the implementation of main categories of different genres. Therefore, this study discusses the impact of $\mathrm{GBI}$ of writing in writing skills of Iranian Intermediate EFL learners in Civil aviation technology college of Tehran and highlights the possible effects of this pedagogy in the students' writing development in four different genres, namely argumentative, discussion, explanation, and exposition regarding coherence, cohesion, and the organization of written texts.

EFL learners enrolled in English language learning courses have various reasons to attend the class, such as further academic studying or improving their job opportunities. These classes should help them understand the social function of genres and the context.

This study is hoped to benefit foreign and second language writing curriculum planners 
and teachers by shedding light on what GBI pedagogy means and how it should be implemented in an actual classroom situation. Therefore, this study can be considered an empirical one in writing pedagogies. In this respect, the following research questions will be under consideration:

1. Does $\mathrm{GBI}$ significantly impact intermediate EFL learners' writing skills such as coherence and cohesion compared to traditional instruction?

2. Does $\mathrm{GBI}$ of writing significantly impact the organization of intermediate EFL learners` writing compared to traditional instruction?

Considering the research questions, the authors proposed the following null hypotheses:

1. $\mathrm{GBI}$ does not significantly impact intermediate EFL learners' writing skills, such as coherence and cohesion.

2. $\mathrm{GBI}$ does not significantly impact the organization of intermediate EFL learners` writing.

\section{Method}

\section{Study design}

The authors selected two participant groups to conduct the study, one as the experimental group and the other as the control group. The study used a quasi-experimental design due to the lack of participants' random selection.

\section{Participants}

The authors selected 51 intermediate EFL learners through convenience sampling. All participants were native speakers of Frasi, having no $\mathrm{GBI}$ experience of writing before the study. Their ages ranged from 20-25, and all of them were male. They were learning general English language courses offered by the foreign language department of civil aviation Technology College in Tehran. They were randomly divided into two groups. The control group consisted of 26 senior aviation students, while the experimental group included 25 students.

\section{Instruments}

The material used for writing instruction was the "Paragraph Development" book written by Arnaudet and Barrett (1990). The participants' proficiency level was determined through the MELAB test (Bridge et al. 1977). The authors selected the MELAB test due to standard format, ease of administration, availability, and consistent scoring. This test consists of 40 grammar items, 40 vocabulary items, and 20 reading comprehension items. Respondents with less than $40 \%$ correct answers are considered elementary, between $40 \%-70 \%$ as intermediate, and above $70 \%$ as advanced learners. In addition, the authors examined the participants' writing proficiency using the IBT TOEFL test. In the TOEFL writing test, the participants should write a welldeveloped essay within 50 minutes: 20 minutes for the integrated task and 30 minutes for independent writing to check their writing homogeneity and proficiency. Pre-tests and post-tests include four independent writing related to four genres which took 120 minutes. Their writing products were measured based on the TOEFL rubric from the Official Guide to the Barron's TOEFL iBT (2009).

According to the Official Guide to TOEFL, scores between 13-16 refer to low intermediate level (general ability to produce a simple limited 
text on familiar topics with limited facility and language errors); based on The Common European Framework of Reference for Languages (CEFR), it is considered level B1. Scores between 17-23 refer to a high intermediate level (typical ability to write in English well on a general topic and produce summaries that include most of the main ideas without difficulty); based on (CEFR), it is considered level B2 level. Therefore, both levels were included in the study as intermediate writing levels.

\section{Data Collection}

First, the authors selected 51 intermediate EFL learners through purposive sampling by administering the MELAB test, which took 120 minutes to complete; then, the authors randomly divided the participants into two experimental (25 participants) and control (26 participants) groups. To ensure participants in both groups are homogenous in terms of their writing skills, the author administered a 50minute Barrons' writing test for TOEFL IBT (2008). After ensuring the participants' writing homogeneity, the authors started the treatment for 12 weeks. Finally, they administered four Barrons' writing tests for TOEFL IBT (2008) lasted for 120 minutes as pretests and post-tests. Raters judged the overall quality of students' written products holistically, considering writing development, organization, appropriate grammar, and wording. The coherence and cohesion, as well as organization of the participants' writing, were quantified for analysis. Interrater reliability was calculated between two raters to ensure consistency and reliability of the rater's score. The book "Paragraph Development," written by Arnaudet and Barrett (1990), was the instruction material used for control and experimental groups. The emphasis in this book lies in developing paragraphs, as the name of the book suggests.

Both groups followed the English language department syllabus and were instructed twice a week for 90 minutes, nearly for three months. The control group was taught to write conventionally, i.e., process writing instruction (pre-writing, writing, post writing). The participants practiced paragraph structures such as cause and effects, compare and contrast definition, and enumeration implicitly. To sharpen students ' writing skills in the control group, the teacher stimulated pre-writing to evoke the participants' previous knowledge about the topic. He modeled a paragraph, and students followed its structure to write a paragraph independently. The teacher gave them helpful feedback, and they edited their writing again.

The students in the experimental group practiced genre-based pedagogies. They were explicitly taught argumentative, explanation, exposition, and discussion genres through Widodo's (2006) lesson plan. First, the teacher discussed the basic features of each genre using a relevant model for every genre as an example. Afterward, the students tried to analyze another model with the teacher's help. Then, students wrote their first draft in classroom discussions and got feedback from their peers and their teacher. Finally, they wrote the final draft independently. Explicit instruction on textual and structural features of the genres above consists of four phases: Field knowledge, modeling, joint construction, and independent construction.

Infield knowledge, while reading a model text, the instructor introduced verb tenses, 
vocabulary, adjectives, and different kinds of expressions used in that specific genre. In modeling, the instructor gave hints and tips about the social purpose of that genre, i.e., field, clarified the relationships between participants of that event, i.e., tenor, and finally identified the medium of communication used by participants, i.e., mode (Thompson, 2001). Then, students gradually compared and contrasted the language characteristics used in that genre. In joint construction, students began to construct target text together by gaining a deeper understanding of four genres. At this phase, it was important for the teacher to repeat the grammatical patterns of that genre. After repeating similar grammar activities, the students felt independent to develop grammatical points that they could not learn before. In independent construction, the students could independently construct an example of each genre text type, i.e., description, definition, exemplification, and narration. The teacher played a consultant's role. Students needed feedback and direct support, and they had more confidence and satisfaction in their construction phase.

\section{Data Analysis}

Pre-tests and post-tests of both groups were analyzed through independent sample t-tests using SPSS application version 17 to check the impacts of $\mathrm{GBI}$ on writing. In addition, these tests were evaluated according to a criteriareferenced assessment adapted from Lin (2008) to check students' progress regarding coherence, cohesion, and organization of their writings.

\section{Findings and Discussion}

\section{Results}

This study attempted to answer the following questions: Does GBI significantly impact intermediate EFL learners' writing skills such as coherence and cohesion? Does GBI of writing significantly impact the organization of intermediate EFL learners' writing? The developments of both groups regarding writing skills (coherence, cohesion, and organization) were analyzed quantitatively according to the criterion-referenced assessment. The statistical analyses were based on descriptive and inferential statistics. The probability level of $p<.05$ was used to determine the significance throughout the study. First, the authors checked the homogeneity of the students in the control and experiment groups in terms of writing proficiency by comparing their writings as depicted in Table 1.

\section{Table 1}

Comparison of writing pre-tests between groups (traditional writing instruction vs. GBI of instruction)

\begin{tabular}{llllll}
\hline Group & Mean & SD & T & DF & Sig. \\
\hline Traditional writing instruction & 16.23 & 2.06 & 0979 & 49 & .332 \\
GBI of writing & 15.54 & 2.98 & & & \\
\hline
\end{tabular}

The mean scores of both control $(m=16.23)$ and experiment $(m=15.54)$ groups were close before treatment. To ensure that this difference is statistically significant, the authors used an independent sample t-test. As depicted in Table 1, the P-value is larger than .05, which 
implies this difference is not significant. Therefore, it can be concluded that the students in both groups were homogenous in terms of writing proficiency before treatment.

To answer research questions, the authors compared post-tests of two groups to see if GBI of writing significantly impacts on four genres' coherence and cohesion, including argumentative, explanation, exposition, and discussion. The second research question tries to find the impact of $\mathrm{GBI}$ on writing on the organization of the essay. Like coherence and cohesion, this criterion was assessed through a criterion-referenced assessment taken from Lin (2008).

Pre-test scores of the control group, i.e., traditional writing instruction ( $M=34.76$, $\mathrm{SD}=2.99$ ) and experimental group, i.e., $\mathrm{GBI}$ of writing $(M=34.69, S D=3.21)$, were very close, which shows both groups performed equally in terms of coherence and cohesion of Argumentative writing before treatment. The following table shows the post-test scores of both groups after treatment.

Table 2

Comparison of both groups post-test mean scores related to coherence and cohesion of Argumentative writing

\begin{tabular}{lllllll}
\hline Groups & No. & Mean & SD & T & DF & Sig. \\
\hline Traditional Instruction & 26 & 34.08 & 3.10 & 10.85 & 49 & .000 \\
GBI of Writing & 25 & 44.89 & 3.93 & & & \\
\hline
\end{tabular}

As depicted in Table 2, the $\mathrm{GB}$ group (M= $44.89, \mathrm{SD}=3.93$ ) outperformed the traditional instruction group $(\mathrm{M}=34.08, \mathrm{SD}=2.56)$. Independent sample t-test showed that this difference is significant $(P<.05)$. So, it can be concluded that the GBI of writing significantly and positively improved EFL learners' argumentative writing's coherence and cohesion. The next investigated genre was the explanation. Pre-test scores of the group with traditional writing instruction ( $M=35.76$, $\mathrm{SD}=2.99$ ) and the group with $\mathrm{GBI}$ of writing $(M=36.23, S D=3.05)$ were very close, which shows both groups performed equally in terms of coherence and cohesion of explanatory writing before treatment. The following table shows the post-test scores of both groups after treatment.

Table 3

Comparison of both groups post-test mean scores related to coherence and cohesion of Explanatory writing

\begin{tabular}{lllllll}
\hline Groups & No. & Mean & SD & T & DF & Sig. \\
\hline Traditional Instruction & 26 & 36.28 & 3.42 & 9.12 & 49 & .000 \\
GBI of Writing & 25 & 44.77 & 3.95 & & & \\
\hline
\end{tabular}

As depicted in Table 3, the GBI group ( $M=$ 44.77, $\mathrm{SD}=3.95)$ outperformed the traditional instruction group $(M=36.28, \quad S D=3.42)$.
Independent sample t-test showed that this difference is significant $(P<.05)$. So, it can be concluded that the GBI of writing significantly 
and positively improved EFL learners' Explanatory writing's coherence and cohesion. The next investigated genre was exposition. Pre-test scores of the group with traditional writing instruction $(M=26.80, S D=2.68)$ and the group with $\mathrm{GBI}$ of writing $(\mathrm{M}=27.00, \mathrm{SD}=2.90)$ were very close, which shows both groups performed equally in terms of coherence and cohesion of expository writing before treatment. The following table shows the posttest scores of both groups after treatment.

Table 4

Comparison of both groups post-test mean scores related to coherence and cohesion of Expository writing

\begin{tabular}{lllllll}
\hline Groups & No. & Mean & SD & T & DF & Sig. \\
\hline Traditional Instruction & 26 & 27.00 & 2.12 & 9.84 & 49 & .000 \\
GBI of Writing & 25 & 32.77 & 3.93 & & & \\
\hline
\end{tabular}

According to Table 4, the GBI group ( $M=$ $32.77, \mathrm{SD}=3.93$ ) outperformed the traditional instruction group $(M=27.00, S D=2.12)$. Independent sample t-test showed that this difference is significant $(P<.05)$. So, it can be concluded that the $\mathrm{GBI}$ of writing significantly and positively improved EFL learners' Expository writing's coherence and cohesion. Finally, the Discussion genre was investigated.

\section{Table 5}

Comparison of both groups post-test mean scores related to coherence and cohesion of Discussion writing

\begin{tabular}{lllllll}
\hline Groups & No. & Mean & SD & T & DF & Sig. \\
\hline Traditional Instruction & 26 & 39.24 & 2.27 & 16.29 & 49 & .000 \\
GBI of Writing & 25 & 47.65 & 1.29 & & & \\
\hline
\end{tabular}

As shown in Table 5 , the $G B I$ group ( $M=$ $47.65, S D=1.29$ ) outperformed the traditional instruction group $(M=39.24, S D=2.27)$. Independent sample t-test showed that this difference is significant $(P<.05)$. So, it can be concluded that the GBI of writing significantly and positively improved EFL learners' Discussion writing's coherence and cohesion.
Pre-test scores of the group with traditional writing instruction $(M=3.72, S D=2.17$, and the group with $\mathrm{GBI}$ of writing $(\mathrm{M}=39.35, \mathrm{SD}=1.95)$ were very close, which show both groups performed equally in terms of coherence and cohesion of Discussion writing before treatment. The following table shows the posttest scores of both groups after treatment. 
writing skills, including coherence and cohesion, is rejected.

The second research question examines if the GBI of writing significantly affects intermediate EFL learners` writing organization compared to traditional instruction. The authors first investigated the Argumentative genre. Pre-test scores of the group with

Table 6

Comparison of both groups post-test mean scores related to the organization of Argumentative writing

\begin{tabular}{lllllll}
\hline Groups & No. & Mean & SD & T & DF & Sig. \\
\hline Traditional Instruction & 26 & 8.68 & 2.56 & 11.80 & 49 & .000 \\
GBI of Writing & 25 & 17.54 & 2.78 & & &
\end{tabular}

As shown in Table 6 , the $\mathrm{GBI}$ group ( $\mathrm{M}=$ $17.54, \mathrm{SD}=2.78$ ) outperformed the traditional instruction group $(\mathrm{M}=8.68, \mathrm{SD}=2.56)$. Independent sample t-test showed that this difference is significant $(P<.05)$. So, it can be concluded that the GBI of writing significantly and positively improved EFL learners' Argumentative writing's organization. After the Argumentative genre, the authors investigated the effect of $\mathrm{GBI}$ on the organization of traditional writing instruction $(\mathrm{M}=7.84$, $\mathrm{SD}=2.24)$ and the group with $\mathrm{GBI}$ of writing $(M=7.81, S D=2.45)$ were very close, which shows both groups performed equally in terms of organization of Argumentative writing before treatment. The following table shows the posttest scores of both groups after treatment. 
treatment. The following table shows the post- test scores of both groups after treatment.

Table 8

Comparison of both groups post-test mean scores related to the organization of Expository writing

\begin{tabular}{lllllll}
\hline Groups & No. & Mean & SD & T & DF & Sig. \\
\hline Traditional Instruction & 26 & 5.64 & 2.66 & 17.93 & 49 & .000 \\
GBI of Writing & 25 & 17.96 & 2.23 & & & \\
\hline
\end{tabular}

As depicted in Table 8, the $\mathrm{GBI}$ group ( $\mathrm{M}=$ 17.96, $\mathrm{SD}=2.23$ ) outperformed the traditional instruction group $(\mathrm{M}=5.64, \mathrm{SD}=2.66)$. Independent sample t-test showed that this difference is significant $(P<.05)$. So, it can be concluded that the GBI of writing significantly and positively improved EFL learners' Expository writing's organization. Finally, the authors investigated the effect of $G B I$ on the organization of Discussion writing. Pre-test scores of the group with traditional instruction of writing $(M=8.92, S D=2.39)$ and the group with $\mathrm{GBI}$ of writing $(\mathrm{M}=8.89, \mathrm{SD}=2.33$ ) were very close, which shows both groups performed equally in terms of organization of Discussion writing before treatment. The following table shows the post-test scores of both groups after treatment.

Table 9

Comparison of both groups post-test mean scores related to the organization of Discussion writing

\begin{tabular}{lllllll}
\hline Groups & No. & Mean & SD & T & DF & Sig. \\
\hline Traditional Instruction & 26 & 9,94 & 2.00 & 17.43 & 49 & .000 \\
GBI of Writing & 25 & 18.77 & 1.81 & & & \\
\hline
\end{tabular}

As depicted in Table 9, the GBI group ( $M=$ $18.77, \mathrm{SD}=1.81$ ) outperformed the traditional instruction group $(\mathrm{M}=9.94, \mathrm{SD}=2.00)$. Independent sample t-test showed that this difference is significant $(P<.05)$. So, it can be concluded that the GBI of writing significantly and positively improved EFL learners' Discussion writing's organization.

Tables 6-9 show that GBI was more effective and positive in improving the organization of intermediate EFL learners' writing compared to traditional instruction. Therefore, the study's second hypothesis, which assumed GBI of writing had no significant effect on participants' writing organization, is rejected.

\section{Discussion}

The current study investigated the impact of teaching Genre-based writing instruction on students' writing skills, including coherence, cohesion, and organization. The study showed its positive effect on coherence, cohesion, and organization. The result confirms the findings of the action research by Antonio et al. (2013), who pointed out the role of explicit teaching in the six steps of the teaching-learning cycle lesson plan proposed by Widodo ( 2006). Furthermore, the outperformance of the participants in generating ideals appropriate to the contexts in several drafting and redrafting phases indicated the efficacy of GBI of writing. This is consistent with the finding of the studies 
by González et al. (2021b), Zhangz and Zhang ( 2021), Nagao (2018), Troyan, (2016) , GuerraLyons, and Nayibe Rosado ( 2020). All of them investigated the explicit instruction of $\mathrm{GBI}$ on main Austlarian genre types such as argumentative and descriptive.

A better understanding of the intended purpose of the target genre, rhetorical moves, self-efficacy, writing independently, and audience awareness are the evidence of the significant role of $\mathrm{GBI}$ in writing instructions. This finding was also revealed in Salehpour et al. (2016), Amjadiparvar ( 2018), and Haerazi et al. (2020). They compared different writing samples in post-intervention of $\mathrm{GBI}$, which motivated and strengthened the learners to the level of writing unassisted. Like Nagao's (2018) study, the current study showed the efficiency of explicit $\mathrm{GBI}$ of writing in improving EFL writing skills. However, Nagao underscores the impact of GBI on different dimensions of lexicogrammatical features in 15 weeks of intervention both quantitatively and qualitatively.

As mentioned before, this study attempts to reap the benefits of applying GBI of writing in a quasi-experimental design. Zhang and Zhang's (2021) study also investigated the efficacy of such classroom instruction in an EFL setting using the same design but different tests, openended questionnaires, and interviews. To highlight the GBI of writing in different Sydney school genre types, Arroyo González et al. (2021b) backed up GBI's effectiveness in a webbased writing instruction utilizing Internet and technology model in contrast with authentic classroom settings in the current study. They also supported the use of integrated GBI to improve the production of the argumentative genre in writing regarding structure, the sociocultural process of writing, and self-efficacy.

The present study quantitatively investigated genre-based instruction of writing four genre types such as argumentative, exposition, explanation, and discussion. In contrast, Guerra-Lyons and Nayibe Rosado ( 2020) investigated the GBI of writing through 3 stages of deconstruction, joint construction, and independent construction in argumentative and expository genres qualitatively. Besides, they recommended explicit $\mathrm{GBI}$ of writing for other academic purposes after scrutinizing the students' recorded attitude of the pedagogy in their collaborative action research.

This study highlighted the beneficiary impact of genre-based writing instruction in an EFL classroom. However, the findings of studies conducted by Rezvani (2019) and Sumekto (2017) lay more emphasis on the psychological impacts of GBI of writing, indicating that the collaborative genre-based instruction of writing can boost the quality of writing due to the teachers' feedback in three genre text types such as recounts, narrative, and descriptive paragraph writing. Moreover, the nuts and bolts of $\mathrm{GBI}$ of writing might unleash the students from the various psychological factors and give them sufficient self-confidence to write on their own. Moreover, Karimpour and Karkia (2016) investigated the organization, rhetorical organization, content, and writing process using a quasi-experimental design quantitatively. The genre in their focus was the description of some summary written texts. They concluded that the students had a better performance by holistically applying genrebased guidelines in their summary writing 
classes which is consistent with the current study's findings.

\section{Conclusion}

To conclude, the researcher aimed to discover if the explicit Genre-based instruction of writing could be beneficial in developing coherence, cohesion, and organization as writing skills. Finding proved that applying Genre-based instruction of writing was very effective and made students produce coherent, cohesive, and well-organized writing pieces. Furthermore, this study showed that GBI of writing could improve content and organization based on the desired genre. Therefore, such a lesson plan helps instructors improve their teaching methods. Also, these guidelines assist students in achieving a better understanding of what they are expected to write by considering text type; so that this approach might be adopted as a supplementary approach to other ordinary writing teaching methods.

More importantly, the explicit instruction of specific genres may create a friendlier classroom where teachers and students would have better collaboration and cooperation in writing assignments, teaching, and learning. The results of this study have pedagogical implications for teaching writing to EFL students. GBI of writing can increase learners' language awareness which helps learners decrease their concern and anxiety since writing has usually been a formidable Task for EFL students, but it cannot free students from the fears of writing appropriate to every context and setting.

Since the study employed a quasiexperimental design in which random sampling could not be applied, we should be cautious in generalizing results to other educational settings. Furthermore, the researcher only investigated the impact of genre-based instruction on coherence, cohesion, and organization, whereas other elements of writing were neglected. Prospective studies can be conducted with different intervening factors such as age and gender, different genre types, or other proficiency levels.

\section{References}

Alavi, S. M., Nemati, M., \& Karimpour, S. (2019). The Impact of Genre-Based Instruction Treatments on EAP Students ' Writing Quality. Journal of Modern Research in English Language Studies., 8(3), 187-206. https://doi.org/10.30479/jmrels.2019.1162 0.1446

Allen, H. W., \& Goodspeed, L. (2018). Textual Borrowing and Perspective-Taking: A GenreBased Approach to L2 Writing. L2 Journal, 10(2). https://doi.org/10.5070//210235331

Almacıoğlu, G., \& Okan, Z. (2018). Genre-based approach to writing instruction for students at an english language and literature department. Eurasian Journal of Applied Linguistics, 4(1), 71-100. https://doi.org/10.32601/ejal.460635

Amjadiparvar, A. (2018). The Effect of SystemNested , Genre-Oriented , StructurallyMediated Model ( SGSM ) of Writing Instruction, and Swalesian Model ( SM ) upon Iranian Learners ' Writing Performance : A Comparative Study. Issue in Language Teaching (ILT), 7(2). https://doi.org/https://doi.org/10.22054/ilt. 2019.36574.342

Antonio, P., Bejarano, C., \& Chapetón, C. M. (2013). The Role of Genre-Based Activities in the 
Writing of Argumentative Essays in EFL. Profile Issues in Teachers' Professional Development, 15(2), 127-147.

Arroyo González, R., Fernández-Lancho, E., \& Maldonado Jurado, J. A. (2021). Learning effect in a multilingual web-based argumentative writing instruction model, called ecm, on metacognition, rhetorical moves and self-efficacy for scientific purposes. Mathematics, 9(17), 1-24. https://doi.org/10.3390/math9172119

Badger, R., \& White, G. (2000). A process genre approach to teaching writing. ELT Journal, 54(2). https://doi.org/10.1093/elt/54.2.153

Bakhtiarvand, M. (2018). Developing EAP Graduate Students Research Article Writing Skills through Genre-based Pedagogy. Applied Linguistics Research Journal, March. https://doi.org/10.14744/alrj.2018.69875

Guerra-Lyons, J. D., \& Nayibe Rosado, M. R. (2020). On the notion of "owning a forest": Ideological awareness and Genre-based Pedagogy in university. DELTA Documentacao de Estudos Em Linguistica Teorica e Aplicada, 36(4), 1-30. https://doi.org/10.1590/1678$460 \times 2020360412$

Haerazi, H., Irawan, L. A., Suadiyatno, T., \& Hidayatullah, H. (2020). Triggering preservice teachers' writing skills through genre-based instructional model viewed from creativity. International Journal of Evaluation and Research in Education, 9(1), 234-244. https://doi.org/10.11591/ijere.v9i1.203945

Han, J., \& Hiver, P. (2018). Genre-based L2 writing instruction and writing-specific psychological factors: The dynamics of change. Journal of Second Language
Writing, $\quad 40$ (November 2017), 44-59. https://doi.org/10.1016/j.jslw.2018.03.001

Hyland, K. (2003). Genre-based pedagogies: A social response to process. Journal of Second Language Writing, 12(1), 17-29. https://doi.org/10.1016/S10603743(02)00124-8

Hyland, K. (2007). Genre pedagogy: Language, literacy and $\mathrm{L} 2$ writing instruction. Journal of Second Language Writing, 16(3), 148-164. https://doi.org/10.1016/J.JSLW.2007.07.00 5

Hyon, S. (1996). Genre in Three Traditions: Implications for ESL. TESOL Quarterly, 30(4), 693. https://doi.org/10.2307/3587930

Karimpour, M., \& Karkia, P. (2016). The Impact of Summary Writing with Structure Guidelines on EFL College Students' Rhetorical Organization: Integrating Genre-Based and Process Approaches. The Journal of Applied Linguistics, 9(18), 158-182.

Kay, H., \& Dudley-Evans, T. (1998). Genre: what teachers think. ELT Journal, 52(4), 308-314. https://doi.org/10.1093/elt/52.4.308

Kuiper, C., Smit, J., de Wachter, L., \& Elen, J. (2017). Scaffolding tertiary students' writing in a genre-based writing intervention. Journal of Writing Research, 9(1), 27-59. https://doi.org/10.17239/jowr2017.09.01.02

M. A. K. Halliday. (1985). An introduction to functional grammar. E. Arnold.

Morell, T., \& Cesteros, S. P. (2019). Genre pedagogy and bilingual graduate students' academic writing. Publications, 7(1). https://doi.org/10.3390/publications70100 08

Morganna, R. (2017). Theoretical, Pedagogical, and Practical Views of Genre Based Instruction. 
ENGLISH FRANCA: Academic Journal of English Language and Education, 1(1), 81. https://doi.org/10.29240/ef.v1i1.153

Nagao, A. (2018). A Genre-Based Approach to Writing Instruction in EFL Classroom Contexts. English Language Teaching, 11(5), 130. https://doi.org/10.5539/elt.v11n5p130

Nasihin, A., Arsyad, S., Harahap, A., \& Chandra, D. E. (2021). The Impact of Using Genre Based Approach to Improve Knowledge and Skill of Writing Reseach Articles Journal for International Journal Publication Social and Humanity Lecturers. American Research Journal of Humanities \& Social Science (ARJHSS), 4(12), 14-24.

Negari, G. M. (2011). A Study on Strategy Instruction and EFL Learners' Writing Skill. International Journal of English Linguistics, 1(2), 299-307. https://doi.org/10.5539/ijel.v1n2p299

Phichiensathien, P. (2018). Genre Based Approach in Academic English Writing. Pasaa Paritat, 1(October), 211-238.

Rezvani, P. (2019). The Effect of Genre-based Instruction of Humorous Narrative Texts on Iranian EFL Learners' Writing Performance. Applied Linguistics Research Journal, 7(1), 229-242.

https://doi.org/10.14744/alrj.2019.74946

Salehpour, S., Saeidi, M., \& Branch, T. (2014). The Effect of Genre-based Scaffolding on Research Paper Writing of MA Candidates in an EFL Context. The Journal of Applied Linguistics, 7(Fall), 91-112.

Sumekto, D. R. (2017). The Effectiveness of PreService English Teachers' Collaborative Genre-Based Writing Feedback. Lingua Cultura, $\quad 11(1), \quad 31$. https://doi.org/10.21512/lc.v11i1.1595
Swales, J. M. (1990). Genre Analysis: English in Academic and Research Settings. In cambridge university press (Vol. 69, Issue 1). Cambridge University Press. https://doi.org/10.2307/416471

Tangpermpoon, T. (2008). Integrated approaches to improve students writing skills for English major students. ABAC Journal, 28(2).

Thompson, G. (2001). Interaction in academic writing: Learning to argue with the reader. Applied Linguistics, 22(1), 58-78. https://doi.org/10.1093/applin/22.1.58

Troyan, F. J. (2016). Learning to Mean in Spanish Writing: A Case Study of a Genre-Based Pedagogy for Standards-Based Writing Instruction. Foreign Language Annals, 49(2), 317-335.

https://doi.org/10.1111/flan.12192

Wang, W. (2017). Learner characteristics in an EAP thesis-writing class: Looking into students' responses to genre-based instruction and pedagogical tasks. English for Specific Purposes, 47, 52-60. https://doi.org/10.1016/j.esp.2017.04.002

Widodo, H. P. (2006). Designing a genre-based lesson plan for an academic writing course. English Teaching: Practice and Critique, 5(3), 173-199.

Zare-ee, A. (2009). The effects of teaching genre moves on EFL learners' performance in letter writing. In Pazhuhesh-e Zabanha-ye Khareji (Issue 49).

Zhang, T., \& Zhang, L. J. (2021). Taking stock of a genre-based pedagogy: Sustaining the development of efl students' knowledge of the elements in argumentation and writing improvement. Sustainability (Switzerland), 13(21).

https://doi.org/10.3390/su132111616 
Atefeh Mohseni 